
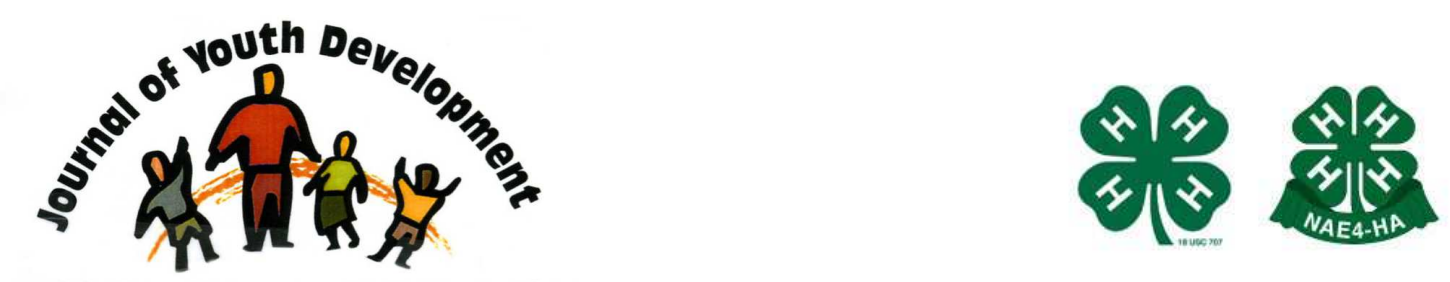

Bridging Research \& Practice

\title{
An Examination of Youth Voice via Quasi-Experimental Methodology
}

\author{
Melissa Cater \\ LSU Ag Center \\ Louisiana State University \\ Baton Rouge, LA \\ mcater@agcenter.Isu.edu
}

Krisanna Machtmes

Louisiana State University

Baton Rouge, LA

machtme@lsu.edu

Janet E. Fox

4-H Youth Development Louisiana State University

Baton Rouge, LA

jfox@agcenter.Isu.edu 


\title{
JOURNAL OF YOUTH DEVELOPMENT \\ bridging research and practice

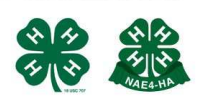

Volume 3, Number 2, Fall 2008

Article 080302FA003

\section{An Examination of Youth Voice via Quasi-Experimental Methodology}

\author{
Melissa Cater, Krisanna Machtmes and Janet E. Fox \\ Louisiana State University
}

\begin{abstract}
The purpose of the study discussed was to determine if youth voice affects the ownership and engagement of youth in a county 4-H program. A youth-led approach was used with the treatment group to facilitate youth and adults sharing decision-making power. The comparison group utilized an adult-centered approach where decisions about the club programming were made strictly by the adults. A preand post-measurement design was used. Analysis of covariance was employed to determine if differences existed between youth participating in the treatment group and comparison groups and if differences existed between youth based on race. Findings indicated statistically significant differences between the treatment and comparison groups on all three constructs and statistically significant differences between Caucasian and non-Caucasian youth on the constructs of ownership and relationship with adults. It was concluded that, in programs incorporating voice, youth experience more ownership and engagement and have a more positive relationship with adults.
\end{abstract}

\section{Introduction}

Nonformal youth development programs provide a place for youth to develop life skills, to become involved in meaningful, challenging activities, and to develop positive relationships with peers and adults. Early indications of the benefits for youth whom are involved in these programs include a decrease in substance abuse and delinquency, an improvement in school performance, and an improvement in overall psychological and social development (National Research Council and Institute of Medicine, 2002; Simpkins, Ripke, Huston, \& Eccles, 2005).

While researchers and practitioners have failed to agree upon a common definition of youth development, there is consensus that a wide range of approaches can lead to positive outcomes (Roth \& Brooks-Gunn, 2003; Roth, Brooks-Gunn, Murray, \& Foster, 1998). Recent research has focused on the importance of retaining youth in high-quality programs. A common challenge 
that is faced by practitioners is the high drop-out rate of youth in out-of-school time programming. Increasingly, researchers are looking at the characteristics of successful programs to try to determine what factors lead to success (Little \& Lauver, 2005). Why are some programs very successful at engaging youth while others seem to operate a "revolving door" program?

Many factors are being considered as part of the success equation. A key issue in youth development programs is the retention of youth in nonformal programs. Youth who do not maintain involvement cannot reap the benefits of participation. Common reasons that youth give for not participating include transportation and safety issues, boredom with the program, and time constraints associated with youths' desire to spend time with friends, work, and family supportive, and conducting care responsibilities (Little \& Lauver, 2005).

\section{Literature Review}

Strategies abound for recruiting and retaining youth. The most familiar ones include program quality features such as providing a sense of safety and belonging, engaging staff who are committed and activities that are both age appropriate and challenging (Lauver \& Little, 2005). The promotion of efforts to include youth in leadership and decision-making roles has grown in popularity over the last eight years. As the literature on this subject has evolved, words like "youth empowerment," "youth decision-making," and "youth voice" have become more prevalent. Studies of the supports and barriers to youth involvement in these roles frequently cite the importance of the adult's role in the program as well as the opportunities provided for youth to have a voice (Anderson-Butcher, 2005; Golombek, 2002; Larson, Walker, \& Pearce, 2005; Pearson \& Voke, 2003).

As the literature on youth development, youth-adult partnerships, youth engagement, and youth ownership have evolved, youth voice is repeatedly mentioned as an important factor in the development of engagement and ownership. Witt (personal communication, March 5, 2008) broadly defined youth voice as "the perception that one's opinions are heard and respected by others - particularly adults." The United Nations (1989) outlined children's rights to a voice in Article 12 of Convention on the Rights of the Child stating that if that child is capable of forming views then he or she has the right to express those views. The article goes on to state that these views should be taken into account in legal matters that pertain to the child. Lansdown (2001) clarified this to mean that all children are capable of articulating their views either through speech or other communication forms, and adults have a responsibility to provide the opportunity for this expression to occur.

Practitioners commonly cite voice as a best practice for youth programming, and researchers mention it as a contributor to ownership and engagement. For instance, Quinn (1999) and Mead (2003) observed that the inclusion of voice during the planning stages, as well as throughout the program, is a key best practice in youth development programs. Frank's (2006) review of literature included studies of youth participants in the field of community and environmental planning. Frank's (2006) research revealed the inclusion of increased youth voice and increased youth responsibility as commonly cited conditions for effective youth participation. In order for this to occur, a corresponding relinquishment of some of the adults' power was needed.

Cruz's (2004) case study of youth participating in a neighborhood planning and design club found that as a result of involvement, youth realized that their ideas were important and that 
they could make a difference when allowed to have a voice in the process. Although she does not specifically name it "youth voice," Anderson-Butcher (2005) listed the practice of giving youth a say in how the program is planned and implemented as a means to encourage autonomy and independence in youth, and she named these as important indicators of retention. Jones (2004) frequently mentioned the level of voice as an essential factor in the type of relationship developed between youths and adults. He posited that youth voice was an important element in any relationship, regardless of whether it was adult-led or youth-led. In describing the principles and values that were the basis of effective youth-adult partnerships, Camino (2000) noted that youth wanted to have a say, wanted to be heard, and wanted to be treated as an equal partner. As pointed out in the Convention on the Rights of the Child, these are all elements of youth having a voice.

\section{Purpose of Study}

Youth development programs struggle with retaining youth in their programs, especially teenaged youth. Understanding what motivates youth to develop ownership, and to become more engaged in the program, is essential to the development of high-quality youth development programs that meet the needs of youth. Programs that cannot retain youth will not have an opportunity to impact youth. Youths' perceptions of their degree of voice play an important role in their decision to remain with (or depart from) a program. Because of the important role that adults play in facilitating the development of voice, understanding how youth perceive their interactions with adults would provide insight into strengths and weaknesses of the interactions that could be addressed through training programs for adults who work with youth. The research in the area of youth perceptions of voice in programs primarily targeting youth development is limited. This study provides an opportunity to better understand how youth experience the development of voice in a program specifically targeting youth developmental outcomes.

\section{Method}

\section{Sample}

During the 2005-2006 school year, 193 high school youth in a north Louisiana parish (county) participated in the in-school 4-H club program. Every high school student in the parish was offered the opportunity to join a local school 4-H club, and those who chose to join became local club members. One school club was purposefully selected to serve as the treatment group while the other three high school clubs served as the comparison group.

The treatment group consisted of a high school 4-H club whose population is made up of eighth through twelfth graders. During the 2005-2006 school year, there were 295 students registered at the school, and $53.9 \%$ of the student population was eligible for free or reduced price lunches. Of the 295 students in the school, 86 students chose to join the local 4-H club and thus were members of the treatment group. The comparison group consisted of the other three high school clubs in the parish. One of the high school 4-H clubs included an enrollment of seventh through twelfth graders, while the school population consisted of kindergarten through twelfth graders. There were 77 students registered at the school, and $64.94 \%$ of the students in K-12 qualified for free or reduced price lunches. The other two high school clubs in the comparison group consisted of ninth through twelfth graders. One school had an enrollment of 70 students, with $81.43 \%$ qualifying for free or reduced price lunches. The other school enrolled 91 students for the 2005-2006 school year, and 33\% of those qualified for free or reduced price lunches. The student enrollment for the three schools comprising the comparison 
groups was 238 students, of which 107 chose to join their local 4-H club. In the comparison group, an overall proportionalized average of $57.6 \%$ of the students qualified for free or reduced price lunches as compared to the $53.9 \%$ of students qualifying for free or reduced price lunches in the treatment group (A. Guarino, personal communication, January 23, 2006).

\section{Procedure}

The Louisiana 4-H program utilizes an in-school club setting as the predominant delivery mode for the educational component of the program. The 4-H club year began with a standard enrollment period for all county $4-\mathrm{H}$ members during the month of September. The treatment group club program evolved within a semi-structured framework designed to allow the participants a voice in determining the tone and direction the club would take with an emphasis on creating a program that was youth-led.

During the first meeting, members were given examples of roles that youth were assuming in organizations: program planner, trainer, evaluator, conference planner, advisory committee member, funder, and youth advocate. Youth were challenged to brainstorm ideas in small groups for roles that their club could assume. Suggestions from the small group discussions were shared with the larger group. Members reviewed the list of ideas and voted to explore the possibility of providing more school-based activities in which youth could become involved, essentially assuming a program planning role. They again used small group discussions to brainstorm ideas for activities to propose. Lists were combined and results were evaluated by the large group. The group discussed next steps, including identifying keys to success and building administrative support. A survey of interests was developed by club members and administered to the school student body.

Following the survey, members researched the top three topics of interest to the student body and reported findings to the club. Youth members debated the pros and cons of the proposed activities, finally reaching consensus on their proposal which was then taken to the school principal. This iterative process provided a mechanism for youth to have a voice and to determine the structure of the club while pursuing a path that was both personally and collectively meaningful.

In the comparison group meetings, a traditional, adult-centered program was conducted. Youth conducted a short business meeting consisting of the recitation of the American and 4-H pledges and reports from the secretary and treasurer. Educational topics for each month's meeting were chosen and presented by the adult leader and included a hands-on activity for club members. Youth had no voice in planning the direction of the club program yet were actively encouraged to take part in the hands-on activities in the club.

\section{Data Collection}

The researcher collected data from youth in the treatment and comparison groups through prepost surveys. A pretest was given to all youth in both the treatment and comparison groups in October 2005 to ascertain youths' perception of voice. The posttest was given in May of 2006. 


\section{Data Analysis}

Demographics for youth in the treatment and comparison groups are presented in Table 1.

Table 1

Demographic Characteristics of Youth Participants $(\mathrm{N}=193)$, In Percents

\begin{tabular}{|c|c|c|}
\hline Youth Characteristic & Treatment Group & Comparison Group \\
\hline $\begin{array}{l}\text { Gender } \\
\text { Female } \\
\text { Male } \\
\end{array}$ & $\begin{array}{l}72.1 \\
27.9\end{array}$ & $\begin{array}{l}59.8 \\
40.2 \\
\end{array}$ \\
\hline $\begin{array}{l}\text { Age } \\
\begin{array}{r}12 \\
13 \\
14 \\
15 \\
16 \\
17 \\
18 \\
19\end{array}\end{array}$ & $\begin{array}{r}0.0 \\
8.3 \\
20.2 \\
22.6 \\
27.4 \\
13.1 \\
7.1 \\
1.2\end{array}$ & $\begin{array}{r}0.9 \\
2.8 \\
18.7 \\
24.3 \\
20.6 \\
27.1 \\
5.6 \\
0.0\end{array}$ \\
\hline $\begin{array}{l}\text { Race } \\
\text { Caucasian } \\
\text { Non-Caucasian }\end{array}$ & $\begin{array}{l}67.4 \\
32.6 \\
\end{array}$ & $\begin{array}{l}81.3 \\
18.7\end{array}$ \\
\hline $\begin{array}{c}\text { Number of Years in } 4-\mathrm{H} \\
1 \\
2 \\
3 \\
4 \\
5 \\
6 \\
7 \\
8 \\
9 \\
10\end{array}$ & $\begin{array}{c}8.1 \\
11.6 \\
9.3 \\
15.1 \\
19.8 \\
14.0 \\
15.1 \\
2.3 \\
4.7 \\
0.0\end{array}$ & $\begin{array}{r}5.6 \\
4.7 \\
4.7 \\
6.5 \\
7.5 \\
21.5 \\
15.9 \\
15.9 \\
16.8 \\
0.9\end{array}$ \\
\hline $\begin{array}{l}\text { Number of Years in } 4-\mathrm{H} \\
\text { Junior Leader Club } \\
0 \\
1 \\
2 \\
3 \\
4\end{array}$ & $\begin{array}{r}88.4 \\
2.3 \\
3.5 \\
5.8 \\
0.0 \\
\end{array}$ & $\begin{array}{r}82.2 \\
8.4 \\
5.6 \\
2.8 \\
0.9\end{array}$ \\
\hline
\end{tabular}

Youths' perceptions of engagement, ownership, and relationship with adults were measured using a researcher-developed instrument, the Youth Voice Survey. Analyses of covariance were conducted to compare the Youth Voice Survey sub-scale post-measurement summated scores for youth in the youth-led club with those of the youth in the adult-led club on the variables group and race. Responses for those youth who had missing or incomplete data were deleted from the analysis, resulting in the following usable responses: Model 1, Relationship with Adults $(n=124 ; M=23.51 ; S D=4.422)$; Model 2, Engagement $(n=120 ; M=24.78 ; S D=$ 4.129); and Model 3, Ownership, $(n=123 ; M=13.38 ; S D=3.074)$. 
In order to determine which interval variables to use as covariates, a bivariate correlation was conducted between the post-measurement summated scores for each factor and the interval level demographic variables. Results indicated that Number of Years in Junior Leader Club was the most significant demographic variable in each subscale using a .05 Alpha level on a twotailed test of significance and was appropriate for use as a covariate. Additionally, premeasurement summated scores were also utilized as a covariate. The decision to use these variables as covariates was supported by their entry into the regression model at significance. Further support for the validity of including Number of Years in Junior Leader Club as a covariate was provided by a reduction in the error terms when modeling the regression relationship.

Analyses of covariance were conducted using the post-measurement summated scores for each of the three subscales: Relationship with Adults; Engagement; and Ownership. For each subscale analysis, a Levene's test of homogeneity of variances and a lack of fit test were examined. Results of these tests for each subscale were non-significant, indicating that variances were homogeneous for all three scales and that model fit was good for each of the three scales.

Analysis of covariance assumes that the slope of the regression relationship between the covariates and the response is the same for all factor levels (Freund \& Wilson, 2003; Kutner, Nachtsheim, Neter, \& Li, 2005). In order to test this assumption, the full model for each subscale was analyzed including main effects and interactions. These analyses utilized type one sums of squares. The tested interaction terms for each subscale included each of the following: Group * Pretest Summated Scores; Group * Junior Leader Years, Race * Pretest Summated Scores; and Race * Junior Leader Years (See Table 2).

Table 2

Interaction Terms $\underline{F}$ Statistics and Significance Levels

\begin{tabular}{|c|c|c|c|c|}
\hline & $\begin{array}{c}\text { Group * Pretest } \\
\text { Summated Scores }\end{array}$ & $\begin{array}{l}\text { Group * Junior } \\
\text { Leader Years }\end{array}$ & $\begin{array}{l}\text { Race * Pretest } \\
\text { Summated } \\
\text { Scores }\end{array}$ & $\begin{array}{l}\text { Race } * \text { Junior } \\
\text { Leader Years }\end{array}$ \\
\hline $\begin{array}{l}\text { Relationship with } \\
\text { Adults Subscale } \\
\qquad \frac{F}{\underline{p}}\end{array}$ & $\begin{array}{r}1.583 \\
.211 \\
\end{array}$ & $\begin{array}{l}.120 \\
.730\end{array}$ & $\begin{array}{r}2.678 \\
.104 \\
\end{array}$ & $\begin{array}{r}2.417 \\
.123\end{array}$ \\
\hline $\begin{array}{l}\text { Engagement } \\
\text { Subscale } \\
\quad \frac{F}{p} \\
\end{array}$ & $\begin{array}{r}1.219 \\
.272 \\
\end{array}$ & $\begin{array}{r}2.688 \\
.104 \\
\end{array}$ & $\begin{array}{l}.003 \\
.955\end{array}$ & $\begin{array}{l}.402 \\
.527\end{array}$ \\
\hline $\begin{array}{l}\text { Ownership Subscale } \\
\frac{\mathrm{F}}{\mathrm{p}}\end{array}$ & $\begin{array}{l}.698 \\
.405\end{array}$ & $\begin{array}{l}.029 \\
.865\end{array}$ & $\begin{array}{l}.901 \\
.345\end{array}$ & $\begin{array}{r}1.389 \\
.241 \\
\end{array}$ \\
\hline
\end{tabular}

In each model, none of the interaction terms were significant, thus confirming the assumption that the slope of the regression relationships between the covariates and the response were the same for all factor levels. Therefore, the interaction terms were deleted from the model and only the main effects were analyzed. 
Main effects for the independent variables, group and race, were tested for each of the subscales (See Table 3). For the Relationship with Adults subscale, both independent variables were significant, although an R squared value of .216 (and an adjusted R squared value of .190) were returned for this model indicating that a substantial amount of variance was still unexplained. Partial Eta squared was used to determine the effect size of the model. An effect size of .216 was returned, indicating a low effect size (Sheskin, 2004).

Analysis for the Engagement subscale indicated that the independent variable, group, was significant (See Table 3). An R squared value of .266 (and an adjusted R squared value of .240) were returned for this model, indicating that a substantial amount of variance was still unexplained by the model. An effect size of .266, based on Partial Eta squared, indicated a low effect size (Sheskin, 2004).

In analysis of the final subscale, Ownership, both independent variables, group and race, were significant (See Table 3). An R squared value of .339 (and an adjusted $\mathrm{R}$ squared value of .317) were returned for the model, indicating that a substantial amount of variance was still unexplained by the model. Partial Eta squared was used to assess effect size, with .339 denoting a low effect size (Sheskin, 2004).

\section{Table 3}

Analysis of Covariance of POST Measurements of Perception of Youth Voice Using Subscale Summated Scores Controlling for PRE Measurements of Perceptions of Youth Voice Using Subscale Summated Scores and for Number of Years in Junior Leader Club

\begin{tabular}{|l|c|c|c|}
\hline & $\begin{array}{c}\text { Relationship with Adults } \\
\text { Subscale }\end{array}$ & Engagement Subscale & Ownership Subscale \\
\hline Group & & & 1 \\
df & 1 & 1 & 52.699 \\
Mean Square & 93.959 & 95.923 & 8.165 \\
$\underline{F}$ & 5.932 & 7.406 & .005 \\
$\underline{p}$ & .016 & .008 & .065 \\
Partial Eta ${ }^{2}$ & .047 & .061 & 1 \\
\hline Race & & & 101.070 \\
df & 1 & 1 & 15.659 \\
Mean Square & 68.611 & 27.465 & $<.001$ \\
$\underline{F}$ & 4.332 & 2.121 & .117 \\
$\underline{p}$ & .040 & .148 & 1 \\
Partial Eta ${ }^{2}$ & .035 & .018 & 91.532 \\
\hline Pretest & 1 & 1 & 14.181 \\
df & 244.174 & 243.202 & $<.001$ \\
Mean Square & 15.417 & 18.777 & .107 \\
$\underline{F}$ & $<.001$ & $<.001$ & 1 \\
$\underline{p}$ & .115 & .140 & 146.107 \\
Partial Eta & & & 22.636 \\
\hline Junior Leader Years & 1 & 1 & $<.001$ \\
df & 113.487 & 172.294 & .161 \\
Mean Square & 7.165 & 13.303 & 118 \\
$\underline{F}$ & .008 & $<.001$ & 6.455 \\
\hline$\underline{p}$ & .057 & .104 & 122 \\
\hline Partial Eta ${ }^{2}$ & 119 & 115 & \\
\hline Error & 15.838 & 12.952 & \\
df & 123 & 119 & \\
Mean Square & & & \\
\hline Total & & & \\
df & & & \\
\hline
\end{tabular}




\section{Implications and Recommendations}

In each subscale- Relationship with Adults, Engagement, and Ownership- analysis of the results for the independent variable (group) indicated statistically significant differences between the treatment group, which utilized a youth-led model characterized by high levels of youth voice, and the comparison group, which employed an adult-centered leadership model (See Table 4). This suggests that youth in the treatment group felt that they had a more equal relationship with adults than did those youth in the comparison group. Results for the Engagement and Ownership subscales indicate that having a voice increased treatment group youths' perceptions that their participation in the meetings was more important to the functioning of the club, and that they held more power and control in the club than the comparison group youth did (See Table 4).

Table 4

Subscale Adjusted Group Means by Group

\begin{tabular}{|l|c|c|}
\hline \multicolumn{1}{|c|}{ Subscale } & $\begin{array}{c}\text { Treatment Group } \\
\text { Adjusted } \underline{\mathrm{M}}\end{array}$ & $\begin{array}{c}\text { Comparison Group } \\
\text { Adjusted } \underline{\mathrm{M}}\end{array}$ \\
\hline Relationship with Adults & 24.12 & 22.67 \\
\hline Engagement & 25.26 & 24.16 \\
\hline Ownership & 13.66 & 12.52 \\
\hline
\end{tabular}

Previous research has pointed to the idea that the relationship between youth and adults is an important factor in the development of engagement and ownership. This research supports that suggestion. An implication of this study is that the training of youth professionals and volunteers in the program is a key factor to successfully implementing programming in which youth have a voice. This is supported in studies by Kirshner, O'Donoghue, and McLaughlin (2005), Mitra (2004), and O'Neill and Barton (2005), who found that the relationship between youth and adults was an important factor in youth developing ownership and taking responsibility for the program. An additional implication of this study is that giving youth voice in developing programs of which they are a part is one way to address the problem of decreasing program participation for older youth.

Analysis of the results for the independent variable (race) indicated that Caucasian youth were more likely to feel equal to adults than non-Caucasian youth were. Interestingly enough, there was no statistically significant difference between Caucasian and non-Caucasian youth on the Engagement subscale, which looked at youths' feelings that their participation in meetings was essential to club function. Yet there was a statistically significant difference between Caucasian and non-Caucasian youth on the Ownership subscale, which measured youths' perceptions of power and control. This finding is similar to what Silva (2002) observed where, over time, participation lagged with those remaining students exhibiting self-confidence and ownership and high levels of engagement. This implies that there is a lack of understanding of how nonCaucasian youth internalize the opportunity to have voice, and implies a need to look at different support systems which may be necessary for non-Caucasian youth to have voice.

\section{Conclusion}

The issue of power is a common theme in many studies (Anderson-Butcher, 2005; Calvert, 2004; Kellett et al., 2004; Kirshner, 2003; Prilleltensky, Nelson, and Peirson, 2001; Royce, 
2004; Valaitis, 2002; Vallerand, 2001), and is a topic that must be addressed via training for adults working with youth. The basic theme that adults are not giving up all of the power to youth, but are instead sharing the power equally with youth, should be a guiding tenet embedded in training. A recommendation is made to provide adults with training in ways to balance youth ownership with adult ownership of the program. Furthermore, the thought that increased engagement and ownership might lead to retention of youth points to the need for attendance records by individual. These records could be used as a tracking mechanism to determine if increasing youths' perceptions of ownership and engagement does in fact lead to retention of youth in the program.

The findings of this study indicate that giving youth voice in the program results in increased feelings of engagement and ownership. Additionally, youth feel a closer connection to adults in the program because of the trust that is built when decision-making power is shared.

Participation in youth development programs is predicated on the idea that engagement is an essential component of the process if the best outcomes are to be attained for youth. As youth become more engaged in the program, their feelings of responsibility for (and ownership of) the program increase.

Youth development literature describes youth voice as an important component of engaging youth and building ownership. This study explored the connection between youth voice and ownership, and engagement thus providing a better understanding of the concept of youth voice and its contribution to ownership and engagement. It speaks explicitly to the need for clubs that are managed with intentional inclusion of youth voice, and the need for training volunteers to prepare them for their role in facilitating youth voice and the dynamics of power inherent in this process. While the statistical interpretation of effect sizes [as suggested by Sheskin (2004)] indicated a low effect, this study is one of the first to look at youth voice as it relates to youths' perceptions of ownership and engagement using a quasi-experimental methodology. Additional research is needed to better understand this phenomenon.

\section{References}

Anderson-Butcher, C. (2005). Recruitment and retention in youth development programming. The Prevention Researcher, 12(2), 3-6.

Calvert, M. (2004). Youth development, participation and school reform: Creating opportunities and supports for student decision-making in a high school. Dissertation Abstracts International, DAI-A 65(04), 1311. (UMI No. 3127982)

Camino, L. (2000). Youth-adult partnerships: Entering new territory in community work and research. Applied Developmental Science, 4(Suppl. 1), 11-20.

Cruz, M. (2004). Enriching youth engagement: An evaluation of a participatory planning and design prototype. Unpublished master's thesis, University of Manitoba, Winnipeg, Canada.

Frank, K. (2006). The potential of youth participation in planning. Journal of Planning Literature, 20(4), 351-371.

Freund, R., \& Wilson, W. (2003). Statistical methods (2nd ed.). Boston: Academic Press. 
Golombek, S. (2002). What works in youth participation: Case studies from around the world. International Youth Foundation: Author.

Jones, K. (2004). An assessment of perceptions and experiences in community-based youthadult relationships. (Doctoral dissertation, Pennsylvania State University, 2004). Dissertation Abstracts International, DAI-A 65(12), 4432.

Kellett, M., Forrest, R., Dent, N., \& Ward, S. (2004). "Just teach us the skills please, we'll do the rest": Empowering ten-year-olds as active researchers. Children \& Society, 18, 329-343.

Kirshner, B. (2003, November). The social formation of youth voice. Paper presented at the meeting of the International Conference on Civic Education Research, New Orleans, LA.

Kirshner, B., O'Donoghue, J., \& McLaughlin, M. (2005). Youth-adult research collaborations: Bringing youth voice to the research process. In J. Mahoney, R. Larson, \& J. Eccles (Eds.)., Organized activities as contexts of development: Extracurricular activities, afterschool and community programs. Mahwah, N]: Lawrence Erlbaum Associates.

Kutner, M., Nachtsheim, C., Neter, J., \& Li, W. (2005). Applied linear statistical model(5th ed.). Boston: McGraw-Hill Irwin.

Lansdown, G. (2001). Promoting children's participation in democratic decision-making. Florence, Italy: UNICEF/International Child Development Center.

Larson, R., Walker, K., \& Pearce, N. (2005). A comparison of youth-driven and adult-driven youth programs: Balancing inputs from youth and adults. Journal of Community Psychology, $33(1), 57-74$.

Little, P., \& Lauver, S. (2005). Engaging adolescents in out-of-school time programs: Learning what works. The Prevention Researcher, 12(2), 7-10.

Mead, J. (2003). Map it! And turn up the volume of youth voices. CYD Journal: Community Youth Development, 4(1), 13-18.

Mitra, D. (2004). The significance of students: Can increasing "student voice" in schools lead to gains in youth development? Teachers College Record, 106(4), 651-688.

National Research Council and Institute of Medicine. (2002). Community programs to promote youth development. Washington, DC: National Academy Press.

O'Neill, T., \& Barton, A. (2005). Uncovering student ownership in science learning: The making of a student created mini-documentary. School Science and Mathematics, 105(6), 292-301.

Pearson, S., \& Voke, H. (2003). Building an effective citizenry: Lessons learned from initiatives in youth engagement. Washington, DC: American Youth Policy Forum.

Prilleltensky, I., Nelson, G., \& Peirson, L. (2001). The role of power and control in children's lives: An ecological analysis of pathways toward wellness, resilience and problems. Journal of Community \& Applied Social Psychology, 11, 143-158. 
Quinn, J. (1999). Where need meets opportunity: Youth development programs for early teens. The Future of Children, $9(2), 96-116$.

Roth, J., \& Brooks-Gunn, J. (2003). What exactly is a youth development program? Answers from research and practice. Applied Developmental Science, 72$), 94-111$.

Roth, J., Brooks-Gunn, J., Murray, L., \& Foster, W. (1998). Promoting healthy adolescents: Synthesis of youth development program evaluations. Journal of Research on Adolescence, $8(4), 423-459$.

Royce, S. (2004). "Breaking the culture of silence": An examination of youth empowerment experiences through photovoice. Dissertation Abstracts International, DAI-B 65(08), 3977. (UMI No. 3142850)

Sheskin, D. (2004). Handbook of parametric and nonparametric statistical procedures (3rd ed.)., London: Chapman \& Hall/CRC.

Silva, E. (2002). The broken mic: Student struggles for voice, power, and position in urban school reform. Dissertation Abstracts International, DAI-B 63(09), 3150. (UMI No. 3063551)

Simpkins, S., Ripke, M., Huston, A., \& Eccles, J. (2005). Predicting participation and outcomes in out-of-school activities: Similarities and differences across social ecologies. New Directions for Youth Development, 105, 51-69.

United Nations. (1989). Convention on the rights of the child. Retrieved April 17, 2008, from http://www.crin.org/docs/resources/treaties/uncrc.asp\#Twelve

Valaitis, R. (2002). "They don't trust us; we're just kids." Views about community from predominantly female inner city youth. Health Care for Women International, 23, 248- 266.

Vallerand, R. (2001). A hierarchical model of intrinsic and extrinsic motivation in sport and exercise. In G. Roberts (Ed.), Advances in Motivation in Sport and Exercise (pp.263-319). Champaign, IL: Human Kinetics.

(C) Copyright of Journal of Youth Development Bridging Research and Practice. Content may not be copied or emailed to multiple sites or posted to a listserv without copyright holder's express written permission. Contact Editor at: patricia.dawson@oregonstate.edu for details. However, users may print, download or email articles for individual use.

ISSN 2325-4009 (Print); ISSN 2325-4017 (Online) 